\title{
COMPUTER BASED TEST (CBT) PADA SEKOLAH TINGGI TARAKANITA JAKARTA MENGGUNAKAN METODE COMPUTERIZED FIXED-FORM TEST (CFT)
}

\author{
Petrus Dwi Ananto Pamungkas \\ Jurusan Teknik Informatika \\ STMIK Bina Insani \\ Jalan Siliwangi No. 6, Rawa Panjang, Bekasi Barat-17113 \\ petrusdwi@binainsani.ac.id
}

\begin{abstract}
Abstrak
Ujian merupakan salah satu tahapan yang biasa digunakan untuk mengevaluasi kemampuan seseorang dalam melakukan serangkaian kegiatan. Dalam serangkaian kegiatan pembelajaran di Sekolah Tinggi Tarakanita juga perlu suatu tahapan dalam mengukur kemampuan seorang mahasiswa. Tahapan ujian tersebut dilakukan dua kali dalam satu semester, yaitu ujian tengah semester dan ujian akhir semester. Dengan jumlah sekitar 900 mahasiswa, setiap ujian berlangsung maka Sekolah Tinggi Tarakanita harus menyiapkan sekitar 64.800 sampai 108.000 lembar kertas atau sekitar 130 sampai 216 rim kertas ukuran F4 (folio) yang hanya digunakan saat ujian berlangsung. Setelah kegiatan ujian selesai maka lembaran soal ujian tidak digunakan dan akan ditumpuk dalam gudang. Selain mendukung program pemerintah dalam kampanye "Go Green" ternyata soal ujian berbasis Computer Based Test (CBT) juga mampu menghemat biaya sampai $80 \%$ untuk setiap kali kegiatan ujian berlangsung. Melalui integrasi Learning Management System (LMS) yang dibangun di Sekolah Tinggi Tarakanita maka soal ujian berbasis Computer Based Test (CBT) ini dapat dilaksanakan dengan baik. Dengan menggunakan metode penelitian eksperimen maka dirancang sebuah aplikasi soal ujian berbasis Computer Based Test (CBT). Sedangkan metode pengembangan aplikasi yang digunakan adalah waterfall model dengan black box testing sebagai metode yang dipilih untuk pengujian aplikasi. Adapun hasil ujicoba aplikasi menunjukkan bahwa soal ujian berbasis Computer Based Test (CBT) dapat dilaksanakan dengan baik melalui dukungan sarana dan prasarana yang sudah tersedia. Bahkan hasil ujian pun dapat langsung diketahui beserta lokasi benar dan salah ada di nomor mana saja. Oleh karena itu, aplikasi ini juga dapat digunakan sebagai latihan dalam persiapan menghadapi ujian.
\end{abstract}

Kata Kunci : Computer Based Test (CBT), soal ujian, ujian.

\begin{abstract}
The test is one of the stages used to evaluate a person's ability to perform a series of activities. In a series of learning activities at Sekolah Tinggi Tarakanita also need a step in measuring ability of a student. Stages of the exam is done twice in one semester, the midterm exam and the final exam of the semester. With about 900 students, each exam is ongoing so Tarakanita High School must prepare around 64,800 to 108,000 sheets of paper or about 130 to 216 reams of $F 4$ size (folio) paper that is only used during the test. After the exam is over, the exam sheet is not used and will be stacked in the warehouse. In addition to supporting government programs in the campaign "Go Green" was a matter of test based Computer Based Test (CBT) is also able to save costs up to $80 \%$ for each time the examination takes place. Through the integration of Learning Management System (LMS) built at Tarakanita High School, this Computer Based Test (CBT) based test can be implemented well. By using the experimental research method then designed an application test questions based on Computer Based Test (CBT). While the application development method used is waterfall model with black box testing as the method chosen for testing the application. The results of the application test show that the question of Computer Based Test (CBT) based test can be done well through the support of facilities and infrastructure that are already available. Even the test results can be directly known along with the correct location and wrong in any number. Therefore, this application can also be used as an exercise in preparation for exams.
\end{abstract}

Keywords: Computer Based Test (CBT), exam questions, exam. 


\section{Pendahuluan}

Peraturan Menteri Riset, Teknologi, Dan Pendidikan Tinggi Republik Indonesia Nomor 44 Tahun 2015 Tentang Standar Nasional Pendidikan Tinggi Pasal 3 (1a) menyatakan bahwa "Standar Nasional Pendidikan Tinggi bertujuan untuk menjamin tercapainya tujuan pendidikan tinggi yang berperan strategis dalam mencerdaskan kehidupan bangsa, memajukan ilmu pengetahuan dan teknologi dengan menerapkan nilai humaniora serta pembudayaan dan pemberdayaan bangsa Indonesia yang berkelanjutan". Terkait dengan hal tersebut maka pemanfaatan teknologi dapat membantu dalam kelanjutan kehidupan berbangsa. Dengan adanya teknologi maka program-program pemerintah dapat terlaksana sesuai harapan, terutama terkait penghematan penggunaan kertas.

Salah satu penyumbang terbesar dari penggunaan kertas adalah pemerintahan dan pendidikan. Untuk bidang pendidikan, misalnya penggunaan buku-buku, modul-modul, materi bahan ajar dan soal ujian yang masih menggunakan kertas sebagai bahan bakunya. Hal tersebut pun terjadi pada Sekolah Tinggi Tarakanita sebagai penyelengara pelaksanaan pendidikan tinggi. Dalam pelaksanaan ujian dibutuhkan banyak kertas untuk mencetak soal ujian dan lembar jawaban. Setelah selesai ujian maka lembaran-lembaran soal tersebut akan menjadi sampah yang sudah tidak terpakai lagi. Adapun kertas-kertas tersebut akan terus menumpuk setiap selesai pelaksanaan ujian dan itu membutuhkan ruangan untuk menampungnya. Untuk mengantisipasi kekurangan tempat penampungan maka pihak kampus akan memusnahkan kertas-kertas. Karena termasuk kategori dokumen rahasia maka tidak sembarangan dalam hal pemusnahan. Banyak biaya yang harus dikeluarkan terkait dengan adanya ujian, mulai dari persiapan sampai dengan selesainya pelaksanaan ujian.

Computer Based Test (CBT) menjadi salah satu alternatif terkait pelaksanaan ujian di Sekolah Tinggi Tarakanita. Selain mendukung program pemerintah, Computer Based Test (CBT) mampu mengurangi biaya pengadaan kertas, ruangan dan kegiatan pemusnahan dokumen serta menghemat waktu koreksi jawaban ujian. Oleh karena itu, perancangan aplikasi soal ujian berbasis Computer Based Test $(C B T)$ diharapkan mampu menjadi alternatif penghematan anggaran dalam pengadaan kertas untuk proses ujian dan mampu menghasilkan laporan hasil ujian seleksi dengan cepat dan akurat.

Penelitian ini dilaksanakan di kampus Sekolah Tinggi Tarakanita (STARKI) Jakarta. Sebagai tempat pembuatan aplikasi Computer Based Test (CBT) menggunakan metode Computer Fixed-form Test (CFT) karena dianggap mampu untuk dilaksanakannya ujian secara bersamaan tetapi dengan urutan pertanyaan yang berbeda untuk masing-masing peserta ujian. Jumlah peserta ujian yang banyak membuat panitia dan pengawas ujian harus lebih bekerja keras guna mengurangi kegiatan-kegiatan kecurangan saat pelaksanaan ujian berlangsung. Karena Computerized Fixed Test (CFT) termasuk ke dalam kategori Computer Based Test (CBT) maka hasil ujian para peserta ujian dapat segera diketahui. Adapun tempat uji cobanya adalah laboratorium komputer dengan matakuliah Komputer Dasar dan Jaringan Online sebagai materi uji cobanya. Teknik pengumpulan data yang digunakan dalam pembuatan aplikasi Computer Based Test (CBT) ini adalah studi pustaka dimana data yang dikumpulkan bersumber dari literatur buku, jurnal dan juga internet. Data-data yang telah terkumpul tersebut kemudian diujicobakan melalui pembuatan aplikasi Computer Based Test $(C B T)$. Hasil pebuatannta berupa prototyping aplikasi untuk membantu proses ujian matakuliah Komputer Dasar dan Jaringan Online.

\section{KAJIAN LITERATUR}

\section{II.1 Evaluasi Pembelajaran}

Menurut Hadi Sutopo (2009) bahwa "evaluasi pembelajaran (ujian) diperlukan untuk mengukur hasil belajar seorang siswa dalam mata pelajaran tertentu. Pada umumnya evaluasi pembelajaran dilakukan secara manual, yaitu menggunakan media kertas. Evaluasi semacam ini memerlukan kehadiran siswa dan pengawas ujian pada tempat dan waktu yang ditentukan; distribusi soal ujian juga memerlukan waktu yang cukup lama, belum lagi jika proses penggandaan soalnya tidak merata sehingga ada beberapa soal ujian yang tidak lengkap sehingga perlu dilakukan penggandaan ulang. Penggunaan kertas sebagai media ujian juga menjadi permasalahan tersendiri, yaitu membutuhkan ruang penyimpanan soal ujian sebelum dan sesudah ujian berlangsung. Permasalahan menjadi semakin kompleks jika ujian sudah selesai, dimana lembaran-lembaran soal ujian akan menumpuk menjadi limbah karena sudah tidak 
mungkin lagi dipergunakan sebagai lembaran soal ujian yang akan datang menyangkut masalah kerahasiaan soal ujian".

Menurut Bernadette Tynan (2004) bahwa "Dalam konteks akademis atau profesional, pengertian ujian merupakan suatu tes yang ditujukan untuk mengukur capaian seseorang setelah ia melalui proses pembelajaran dalam kurun waktu tertentu dengan cara melihat atau menilai kemampuan peserta ujian dalam menjawab atau menyelesaikan sejumlah persoalan yang diberikan. Ada beberapa poin yang perlu digarisbawahi dari pengertian tersebut, yaitu bahwa ujian adalah suatu cara mengukur kemampuan dan pengetahuan peserta didik". Sri Saptina H, dkk (2008) menjelaskan bahwa "Jika dilihat dari segi bentuknya, ujian ini bisa dilakukan secara tertulis, wawancara (tanya-jawab), kegiatan fisik dan lain-lain. Sedangkan dari segi media yang digunakan, ujian tersebut bisa dilakukan dengan menggunakan kertas (paper-based) ataupun komputer (computer-based)".

\section{II.2 Konsep Dasar Computer Based Test (CBT)}

Menurut Batram (2001) bahwa "Tes berbasis komputer atau dikenal sebagai Computer Based Test (CBT) merupakan tes yang diselenggarakan dengan menggunakan komputer. Tes online yang dimaksud disini adalah tes yang diselenggarakan dengan menggunakan komputer dalam bentuk Supervisor mode. Pada model ini terdapat supervisor yang mengidentifikasi peserta tes untuk diotentikasi dan memvalidasi kondisi pengambilan tes. Untuk tes di internet mode ini menuntut administrator tes untuk meloginkan peserta dan mengkonfirmasi bahwa tes telah diselesaikan dengan benar pada akhir tes". Lebih lanjut Batram (2001) menjelaskan "Ada empat bentuk model tes berbasis komputer dan internet yang dikembangkan oleh ITC, yaitu: 1). Terbuka (Open Mode), tes dengan model terbuka seperti ini dapat diikuti siapapun dan tanpa pengawasan siapapun, contohnya tes yang dapat diakses secara terbuka di internet dimana peserta tes tidak perlu melakukan registrasi peserta. 2). Terkontrol (Controlled Mode), tes dengan model seperti ini sama dengan tes dengan model terbuka yaitu tanpa pengawasan siapapun tetapi peserta tes hanya yang sudah terdaftar dengan cara memasukkan username dan password. 3). Supervised Mode, pada model ini terdapat supervisor yang mengidentifikasi peserta tes untuk diotentikasi dan memvalidasi kondisi pengambilan tes. Untuk tes di internet mode ini menuntut administrator tes untuk meloginkan peserta dan mengkonfirmasi bahwa tes telah diselesaikan dengan benar pada akhir tes. 4). Managed Mode, pada model ini biasanya tes dilaksanakan secara terpusat dimana organisasi yang mengatur proses tes dapat mendefinisikan dan meyakinkan unjuk kerja dan spesifikasi peralatan di pusat tes. Mereka juga melatih kemampuan pegawai/staff untuk mengontrol jalannya tes".

Menurut Redecker (2013) bahwa "Secara umum Computer Based Test (CBT) digunakan untuk meningkatkan efisiensi dan efektifitas administrasi tes. Selain itu Computer Based Test (CBT) juga dapat digunakan untuk meningkatkan validitas dan reliabilitas skor tes. Sementara dari aspek siswa, pemanfatan Computer Based Test (CBT) dapat meningkatkan motivasi siswa, meningkatkan konsentrasi dan performance siswa. Dari aspek pengajar, tes dalam bentuk online memberikan keuntungan, yaitu pengajar dapat mempersiapkan materi dengan lebih berkualitas sebagai bahan tes, proses administrasi tes akan standar, dan dapat memonitor motivasi siswa".

Menurut Luecht and Sireci (2011) bahwa terdapat delapan model Computer Based Test (CBT) berdasarkan penggunaan algoritma adaptif, ukuran unit administrasi uji, dan sifat serta sejauh mana perancangan uji otomatis digunakan, antara lain Computerized Fixed-form Test (CFT), Linear On The Fly Test (LOAF), Computerized Adaptive Test (CAT), A Stratified Computerized Adaptive Test (AS), Content Constrained CAT With Shadow Test, Testlet Based CAT, Multistage Computerized Mastery Test, Computer Adaptive Multistage Test. Lebih lanjut Luecht and Sireci (2011) mengatakan tentang metode Computerized Fixed Test (CFT) bahwa "This category of computer-based tests includes preconstructed, intact test forms that are administered by computer to large numbers of students (i.e., preassembled test forms)."

\section{II.3 Computerized Fixed-form Test (CFT)}

Thompson (2003) menyatakan bahwa CFT sebenarnya bentuk evaluasi/uji yang serupa dengan bentuk evaluasi berbasis kertas (PPT, Paper and Pencil Testing), dengan perbedaan bahwa pada CFT soal uji ditampilkan pada computer. CFT digunakan atas pertimbangan praktis antara lain hasil uji dapat langsung dihitung setelah ujian selesai.

Pertimbangan penting dalam menyiapkan CFT adalah bahwa model ini menyatakan bahwa hasil uji harus segera ditampilkan setelah ujian selesai 
sehingga analisis soal dan penskalaan kesulitan soal harus dilakukan sebelum soal dipublikasikan. Pada model ujian yang dilakukan oleh beberapa penguji/pengajar perlu dilakukan pengumpulan soal, analisis beban soal dan distribusi soal jauh sebelum soal dientrikan pada sistem terkomputerisasi.

Bentuk soal pada CFT juga pada umumnya terbagi tiga jenis yaitu multiple choice, short answer dengan jawaban yang dibatasi jumlah katanya, dan true-false.

\section{II.4 Penelitian Yang Relevan}

Penelitian oleh Karfindo dan Firlan Mustafa (2017) dengan judul "Pengembangan Aplikasi Computer Based Test (CBT) untuk Sekolah Menengah Atas (SMA)" memfokuskan pada masalah tidak tersedianya fasilitas untuk pihak guru dalam mengetahui soal-soal ujian mana saja yang sulit bagi siswa sehingga perlu dibahas ulang. Dengan metode web enginnering mampu memberikan ide bagi pengembang maupun user tentang cara sistem akan berfungsi dan yang akan dikembangkan. Adapun hasil penelitian menyimpulkan bahwa aplikasi CBT ini dapat memudahkan guru dalam menganalisa kemampuan siswa, karena guru bisa mengetahui berapa persentasi jawaban yang benar dan salah yang dipilih oleh siswa dan guru juga bisa menganalisa pilihan jawaban apa saja yang dipilih oleh siswa, sehingga guru bisa melakukan pembahasan yang tepat tidak lagi mengulang semua secara keseluruhan.

Adi Pratomo dan Ronny Mantala (2016) melakukan penelitian dengan judul "Pengembangan Aplikasi Ujian Berbasis Komputer Beserta Analisis Uji Guna Sistem Perangkat Lunaknya Menggunakan Metode Sumi (Software Usability Measurement Inventory)" untuk menyelegsaikan masalah bagaimana mengurangi rutinitas yang dilakukan seorang dosen terutama dalam hal mengevaluasi mahasiswa baik UTS (Ujian Tengah Semester) maupun UAS (Ujian Akhir Semester) yang mampu menyita waktu lama karena jumlah mahasiswa yang banyak sehingga kegiatan-kegiatan dosen dalam melaksanakan tridharma perguruan tinggi mejadi terbengkalai. Metode penelitian yang digunakan adalah metode prototyping dengan membuat program aplikasi. Hasilnya terlihat bahwa rutinitas yang dilakukan seorang dosen terutama dalam hal mengevaluasi mahasiswa baik UTS (Ujian Tengah Semester) maupun UAS (Ujian Akhir Semester) menjadi jauh lebih berkurang karena sebagian aktivitas-aktivitas tersebut dilakukan dengan bantuan teknologi.

Penelitian yang dilakukan oleh Petrus Dwi Ananto Pamungkas, Harjunadi Wicaksono, dan Henri Septanto (2015) yang berjudul "Aplikasi Soal Ujian Seleksi Peserta Pelatihan Kejuruan Operator Komputer Berbasis Multimedia Untuk Mendukung Konsep "Paperless Office" Di PPKD Jakarta Timur" mengangkat masalah bagaimana mempermudah dan mempercepat proses penilaian hasil ujian seleksi peserta pelatihan kejuruan operator komputer. Metode prototyping digunakan untuk membuat aplikasi soal ujian seleksi berbasis multimedia. Adapun hasil penelitian dapat dilihat bahwa penggunaan soal seleksi berbasis multimedia mampu terjadi penghematan penggunaan kertas dan waktu untuk pembagian soal dan koreksi jawaban karena soal ujian sudah tersedia pada komputer masing-masing peserta dan nilai secara otomatis sudah dapat dilihat ketika peserta selesai mengerjakan soal ujian tersebut.

\section{Analisis dan Perancangan}

\section{III.1 Analisis Kebutuhan}

Saat ini proses ujian di Sekolah Tinggi Tarakanita masih dilaksanakan manual dengan metode Papaer and Pencils (PPT) dan menghadapi kendala seperti persiapan pelaksanaan ujian yang cukup lama karena pihak panitia ujian harus menggandakan soal ujian agar tercukupi semua peserta ujian, membutuhkan dosen yang banyak sebagai pengawas ujian untuk memperkecil terjadinya usaha kecurangan yang dilakukan peserta ujian, proses pemeriksaan hasil ujian yang cukup lama, terkadang dosen kurang teliti dalam melakukan pemeriksaan hasil ujian mahasiswa, dan membutuhkan banyak kertas sebagai media pelaksanaan ujian serta membutuhkan tempat untuk menyimpan semestara kertas-kertas soal ujian yang tidak terpakai lagi sebelum dimusnahkan.

Berdasarkan hasil analisis atas kondisi saat ini, dipandang perlu dikembangkan aplikasi evaluasi CBT yang dapat memenuhi kebutuhan sebagai berikut:

1. Mengurangi penggunaan kertas untuk menggandakan ujian sehingga dapat menghemat biaya kertas dan menghemat waktu.

2. Menggunakan sistem/aplikasi yang dapat menampilkan soal evaluasi secara acak sehingga dapat mengurangi dan mencegah usaha kecurangan. 
3. Proses pemeriksaan hasil dapat dilakukan secara otomatis dan hasilnya dapat segera terlihat setelah ujian.

4. Arsip pengerjaan evaluasi tersimpan dan dapat ditelusuri ulang oleh peserta ujian maupun dosen penguji.

5. Waktu pengerjaan ujian dapat ditentukan dan dibatasi sesuai dengan kebutuhan.

\section{III.2 Perancangan Aplikasi}

Guna memenuhi kebutuhan sesuai hasil analisis pada uraiana sebelumnya maka perlu dibuat use case yang dapat menggambarkan fungsionalitas aplikasi yang akan dikembangkan.

Use Case aplikasi pada Gambar 1 menggambarkan keterlibatan mahasiswa, dosen, dan pimpinan dengan aplikasi Computer Based Test $(C B T)$ di Sekolah Tinggi Tarakanita (STARKI).

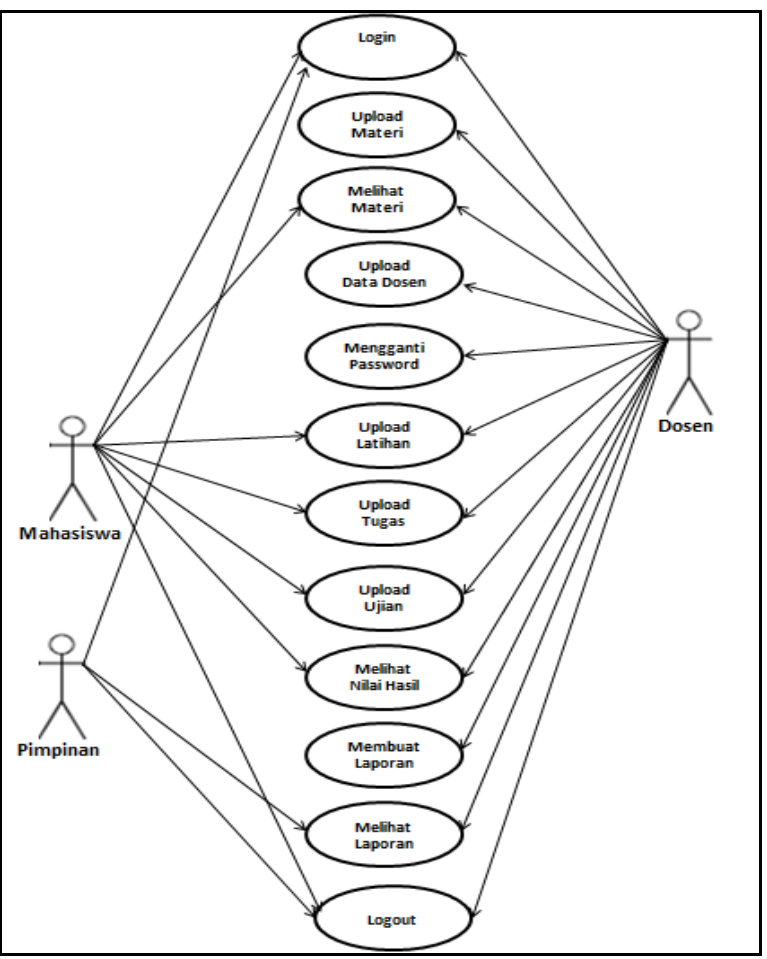

Gambar 1. Use Case Diagram Aplikasi
Dosen membuat soal-soal ujian langsung dalam aplikasi atau diketik dengan mengggunakan aplikasi pengolahan kata terlebih dahulu untuk kemudian minta bantuan operator bagian TI agar memasukkan soal-soal ujian ke dalam aplikasi. Mahasiswa sebagai peserta ujian membuka langsung aplikasi ujian melalui laptop masing-masing untuk login dan mengerjakan soal ujian. Pimpinan program studi menerim laporan hasil ujian peserta ujian yang diberikan masing-masing dosen berdasarkan matakuliah.

Adapun fungsionalitas utama pada aplikasi ini adalah evaluasi/ujian. Untuk menjalankan evaluasi, proses yang dilakukan adalah sebagai berikut:

1. Dosen melakukan login untuk masuk ke dalam aplikasi Computer Based Test (CBT).

2. Setelah melakukan login maka dosen yang berwenang sebagai koordinator matakuliah melakukan input soal ujian yang sudah disiapkan sebelumnya dan melakukan sedikit penyesuaian.

3. Mahasiswa juga diwajibkan melakukan login ke dalam aplikasi Computer Based Test (CBT) untuk dapat mengikuti pelaksanaan ujian.

4. Setelah proses login dinyatakan berhasil maka mahasiswa dapat langsung memulai persiapan pengerjaan ujian. Mahasiswa tersebut dapat langsung menjawab semua soal ujian dengan jangka waktu tertentu.

5. Jika sudah selesai melakukan ujian maka hasilnya dapat langsung dilihat, hasil evaluasi juga menampilkan jawaban benar atau salah sehingga mahasiswa dapat langsung belajar dari hasil ujian yang telah diikutinya.

6. Setelah nilai ujian terakumulasi semuanya maka tugas dosen selanjutnya adalah membuat laporan hasil perkuliahan yang nantinya akan di-upload ke dalam aplikasi sehingga pimpinan program studi dapat melihatnya.

Secara skematis proes di atas dapat digambarkan dalam bentuk Activity Diagram seperit pada Gambar 2. 


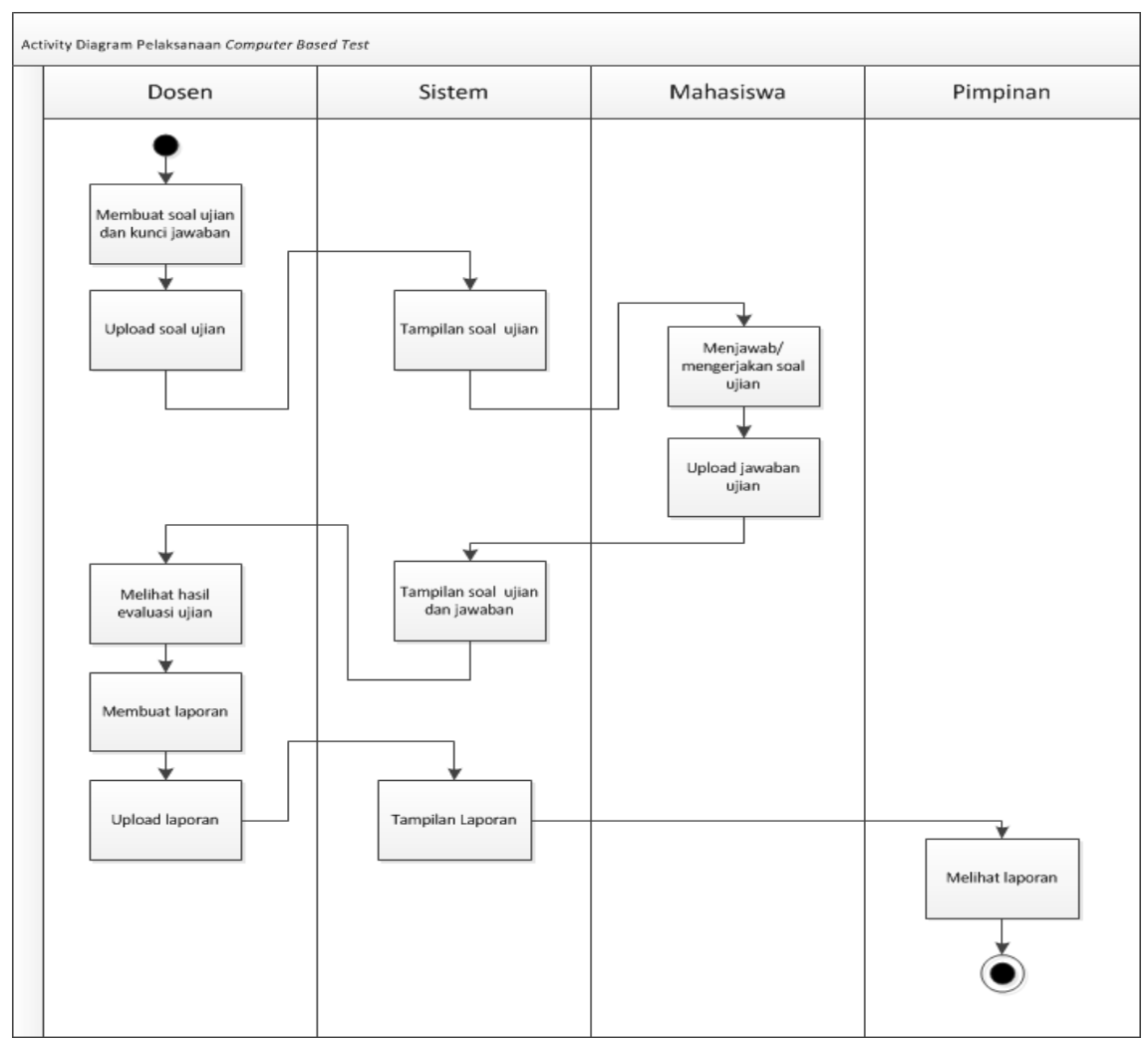

Gambar 2. Activity Diagram Aplikasi

\section{IMPLEMENTASI DAN PENGUJiAn}

\section{IV.1 Implementasi Perancangan}

Implementasi analisis dan perancangan aplikasi di atas kemudian diwujudkan menggunakan fitur evaluasi dari aplikasi Moodle. Pemilihan penggunaan Moodle didasari pada beberapa pertimbangan yaitu:

a. Moodle bersifat opensource dan gratis sehingga dapat digunakan di lingkungan kampus tanpa perlu biaya

b. Moodle relative stabil dan sudah banyak digunakan di kalangan akademis

c. Fitur evaluasi pada Moodle sudah memenuhi semua kebutuhan di atas yaitu pembuatan bank soal, pembuatan paket evaluasi online, penampilan soal secara acak dan penyimpanan hasil evaluasi yang mudah ditelusuri.

d. Kostumisasi pada Moodle relative mudah dan sudah banyak sumber informasi yang relevan terkait implementasi dan kostumisasi Moodle.

Gambar 3 sampai gambar 7 menampilkan antarmuka hasil implementasi Moodle untuk fitur evaluasi online. Tampilan soal ujian berfungsi untuk menampilkan pertanyaan-pertanyaan ujian, seperti terlihat pada Gambar 3 di bawah ini.

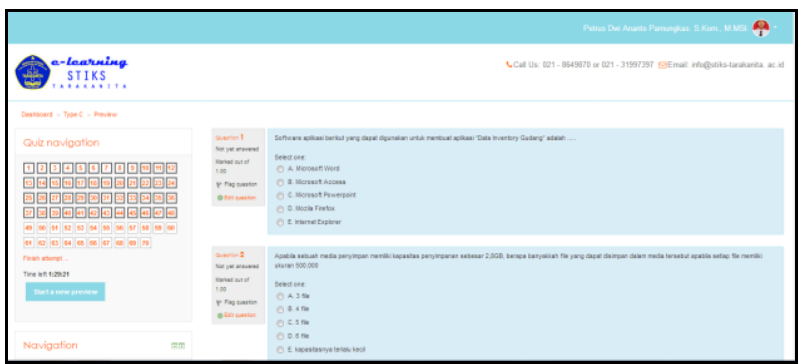

Gambar 3. Tampilan Soal Ujian

Tampilan summary berfungsi untuk mengakumulasi semua jawaban dari user, seperti terlihat pada Gambar 4. 


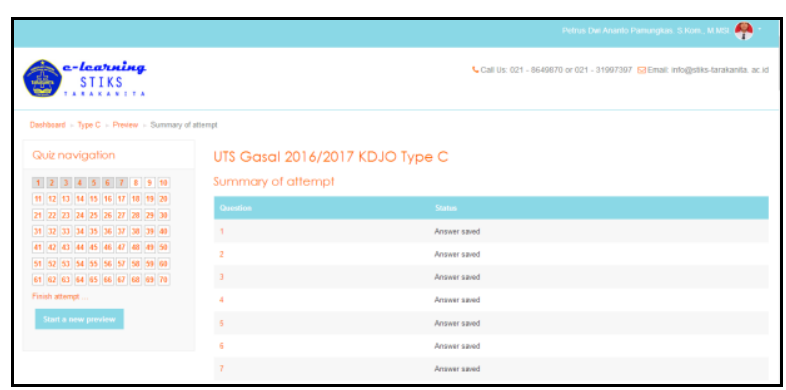

Gambar 4. Tampilan Summary

Setelah peserta mengerjakan ujian, akan terlihat tampilan hasil evaluasi jawaban benar seperti terlihat pada Gambar 5, dan hasil evaluasi jawaban salah seperti pada Gambar 6.

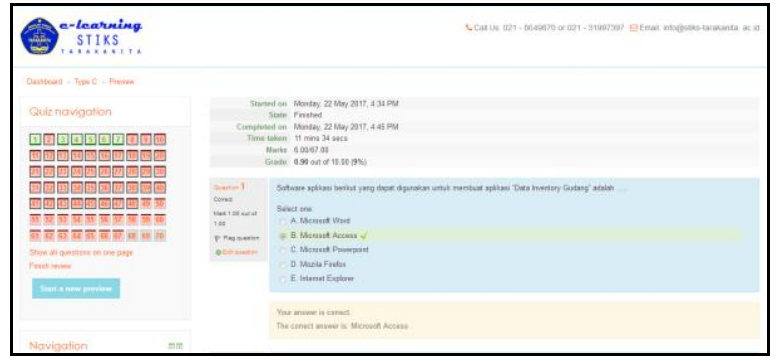

Gambar 5. Tampilan Hasil Evaluasi Jawaban Benar

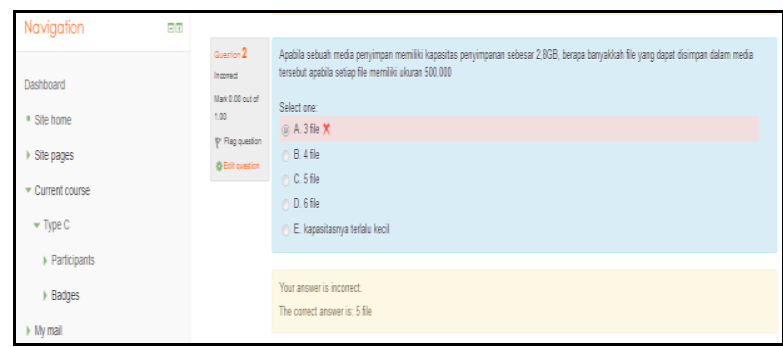

Gambar 6. Tampilan Hasil Evaluasi Jawaban Salah

Tampilan hasil evaluasi keseluruhan berfungsi untuk menampilkan hasil jabawan keseluruhan dari user, seperti terlihat pada Gambar 7 di bawah ini.

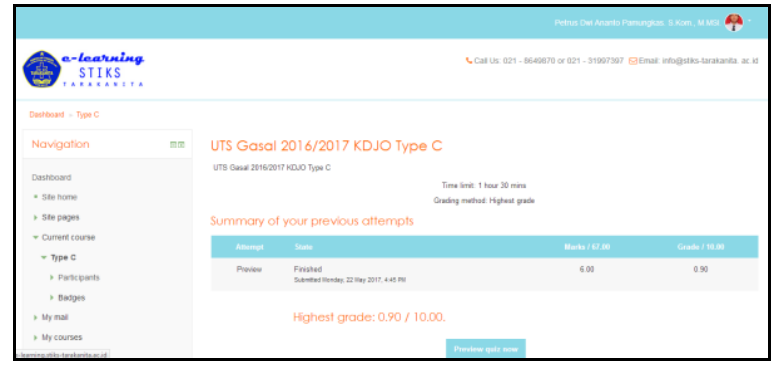

Gambar 7. Tampilan Hasil Evaluasi Jawaban Salah

\section{IV.2 Pengujian Sistem}

Pengujian hasil implementasi aplikasi ini dilakukan dengan metode Blackbox testing. Adapun hal-hal yang akan diuji meliputi fitur-fitur utama seperti pada tabel I. Skenario uji yang akan dikerjakan dapat dilihat pada tabel II.

Berdasarkan scenario dan hasil uji pada tabel II dapat dilihat bahwa seluruh fitur yang diujian sudah berjalan sesuai keinginan.

Tabel 1. Kebutuhan yang Diujikan

\begin{tabular}{|c|c|}
\hline $\begin{array}{c}\text { Kebutuhan } \\
\text { Yang Diujikan }\end{array}$ & Teknis Uji \\
\hline Login user & V Validasi login user \\
\hline Data ujian & Input data soal dan kunci jawaban ujian \\
\hline Tombol Jawaban & Cek jawaban terpilih \\
\hline Review & Tampilan hasil jawaban \\
\hline Laporan & Rekapitulasi hasil evaluasi \\
\hline
\end{tabular}

Tabel 2. Skenario Uji dan Hasilnya

\begin{tabular}{|c|c|c|c|}
\hline $\begin{array}{l}\text { Require } \\
\text { ment }\end{array}$ & Skenario Uji & $\begin{array}{c}\text { Hasil yang } \\
\text { Diharapkan }\end{array}$ & $\begin{array}{c}\text { Hasil } \\
\text { Penguji } \\
\text { an } \\
\end{array}$ \\
\hline \multirow{2}{*}{$\begin{array}{l}\text { Login } \\
\text { User }\end{array}$} & $\begin{array}{l}\text { Input data login } \\
\text { (Jika data } \\
\text { benar) }\end{array}$ & $\begin{array}{l}\text { Tampilan } \\
\text { menu utama }\end{array}$ & Sesuai \\
\hline & $\begin{array}{l}\text { Input data login } \\
\text { (Jika data salah) }\end{array}$ & $\begin{array}{l}\text { Muncul pesan } \\
\text { "Username } \\
\text { atau password } \\
\text { tidak dikenali }\end{array}$ & Sesuai \\
\hline $\begin{array}{l}\text { Data } \\
\text { Ujian }\end{array}$ & $\begin{array}{l}\text { Input Soal dan } \\
\text { Kunci Jawaban } \\
\text { Ujian }\end{array}$ & $\begin{array}{l}\text { Muncul dalam } \\
\text { tampilan ujian }\end{array}$ & Sesuai \\
\hline $\begin{array}{l}\text { Tombol } \\
\text { Jawaban }\end{array}$ & $\begin{array}{l}\text { Cek tombol } \\
\text { jawaban }\end{array}$ & $\begin{array}{l}\text { Muncul } \\
\text { jawaban benar } \\
\text { atau salah }\end{array}$ & Sesuai \\
\hline Review & $\begin{array}{l}\text { Cek tombol } \\
\text { review }\end{array}$ & $\begin{array}{l}\text { Menampilkan } \\
\text { hasil jawaban }\end{array}$ & Sesuai \\
\hline Laporan & $\begin{array}{l}\text { Input } \\
\text { Rekapitulasi } \\
\text { Nilai }\end{array}$ & $\begin{array}{l}\text { Muncul } \\
\text { tampilan } \\
\text { laporan }\end{array}$ & Sesuai \\
\hline
\end{tabular}




\section{KESIMPULAN DAN SARAN}

Berdasarkan hasil uji coba aplikasi di Sekolah Tinggi Tarakanita (STARKI) dapat diketahui bahwa aplikasi Computer Based Test (CBT) ini mampu melihat rekapitulasi hasil pengerjaan ujian serta mempercepat proses penilaian hasil ujian mahasiswa. Kecepatan waktu proses dan keakuratan hasil evaluasi menjadi kekuatan aplikasi ini. Selain itu, aplikasi ini dapat juga dijadikan sebagai latihan dalam persiapan menghadapi ujian karena melalui penggunaan fasilitas review maka terlihat soal-soal mana saja yang sudah benar atau masih salah. Dengan fasilitas ini diharapkan mahasiswa mampu belajar dari kesalahan yang telah dibuat sebelumnya. Dan juga ternyata melalui aplikasi ini pun mampu menghemat penggunaan kertas sebagai media pembuatan soal dan jawaban sehingga biaya yang dikeluarkan untuk membeli kertas dapat dialokasikan ke penggunaan lainnya.

\section{REFERENSI}

Menteri Riset teknologi dan Pendidikan Tinggi Republik Indonesia. 2015. Permenristekdikti Nomor 44 tahun 2015 tentang Standar Nasional Pendidikan Tinggi. Jakarta: Sekretariat Negara Republik Indonesia.

Sutopo, H. Pengembangan Evaluasi Pembelajaran Berbasis Multimedia dengan Flash, PHP, dan MySQL. Jurnal Informatika, Vol. 10, No. 2, November 2009, ISSN: 1693-3877, eISSN: 2407-1544.

Tynan, B. 2004. Melatih Anak Berpikir Seperti Jenius. Jakarta : PT Gramedia Pustaka Utama.

Batram, D., et. al. 2001. Computer-Based Testing and the Internet. USA: University of Massachusetts at Amherst.

Redecker, C. 2013. The Use of ICT for the Assessment of Key Competences. Luxembuorg: Publication Office of the European Union.

Karfindo, F. M. Pengembangan aplikasi Computer Based Test (CBT) untuk Sekolah Menengah Atas (SMA). Register: Jurnal Ilmiah Teknologi Sistem Informasi, Vol. 3, No. 1, Desember 2017. ISSN: 2503-0477 (Print), ISSN: 2502-3357 (Online).
Luecht, R.M. and Sireci, S.G. . 2011. A Review of Models for Computer-Based Testing. New York: The College Board.

Pratomo, A. dan Ronny Mantala. 2016. Pengembangan Aplikasi Ujian Berbasis Komputer Beserta Analisis Uji Guna Sistem Perangkat Lunaknya Menggunakan Metode Sumi (Software Usability Measurement Inventory). POSITIF: Jurnal Sistem dan Teknologi Informasi, Vol. 2, No. 1, November 2016. ISSN: 2460-9552 (Online).

Pamungkas, Petrus Dwi Ananto, Harjunadi Wicaksono, Henri Septanto. 2015. Aplikasi Soal Ujian Seleksi Peserta Pelatihan Kejuruan Operator Komputer Berbasis Multimedia Untuk Mendukung Konsep "Paperless Office" Di PPKD Jakarta Timur. Bina Insani ICT Journal, Vol. 2, No. 1, Maret 2015, ISSN: 2355-3421, e-ISSN: 2527-9777.

Thompson, N.A., 2003, A Proposed Framework of Test Administration Methods, Journal of Applied Testing Methodology, Vol.5, issue 5 , 